\title{
Selected Common Poisonous Plants of the United States' Rangelands
}

\section{By T. Zane Davis, Stephen T. Lee, Michael H. Ralphs, and Kip E. Panter}

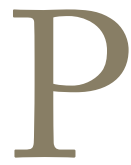

oisonous plants cause large economic losses throughout the rangelands of the world. In the 17 western states of the United States alone, it has been estimated that losses related to the ingestion of poisonous plants exceed $\$ 340$ million annually. However, these estimates include only death and limited reproductive losses: they do not account for lost weight gains, failure to rebreed, veterinary expenses, lost grazing opportunities, and additional feed and care costs. Although numerous plants are associated with significant economic losses, in this article we will review white snakeroot (Eupatorium rugosum), rayless goldenrod (Happlopappus heterophyllus), death camas (Zigadenus spp.), poison hemlock (Conium maculatum), water hemlock (Cicuta spp.), halogeton (Halogeton glomeratus), and broom snakeweed (Guterrezia sarothrae). Other common plants that are associated with large economic losses, such as pine needles (Pinus ponderosa), larkspur (Delphinium spp.), locoweed (Astragalus and Oxytropis spp.), lupine (Lupinus spp.), and the pyrrolizidinealkaloid-containing plants (Senecio, Crotolaria, Cynoglossum, and Amsinckia spp.) are covered in other articles in this issue.

\section{White Snakeroot}

White snakeroot (Eupatorium rugosum or Ageratina altissima var. altissima) is a plant of considerable historical significance that caused countless deaths of Midwestern settlers in the United States during early 1800s. It is believed that in some parts of Indiana and Ohio up to $50 \%$ of the deaths of early settlers were caused by white-snakeroot-induced "milk sickness." Reportedly Nancy Hanks Lincoln, mother of Abraham Lincoln, died from "milk sickness" caused by the family milk cow eating white snakeroot. During the early 1800s white-snakeroot-related illnesses caused many small towns and communities to be abandoned. Even though some astute observers suggested that white snakeroot was responsible for "milk sickness," it was not until 1910 that white snakeroot was unequivocally proven to be the cause of "milk sickness."

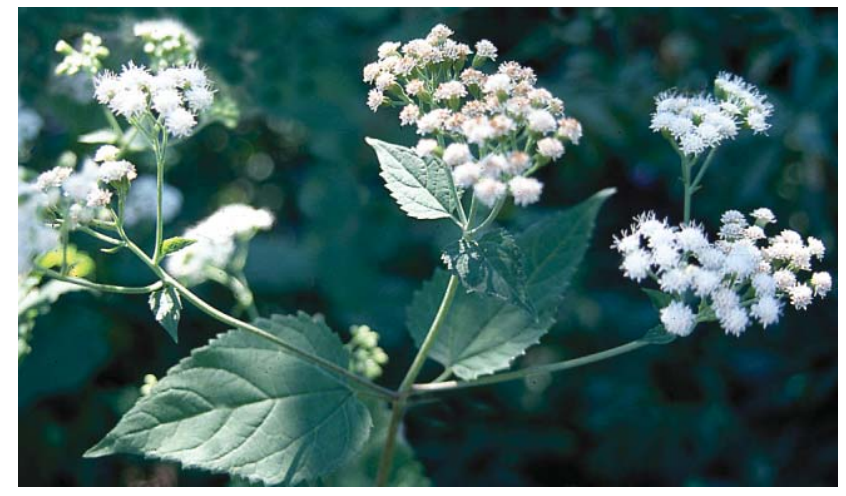

White snakeroot (courtesy of Dr Anthony P. Knight, Colorado State University)

The toxicity of white snakeroot is sporadic and unpredictable. The toxin in white snakeroot is called tremetol and is a mixture of alcohols and ketones that include tremetone, dehydrotremetone, hydoxytremetone, and dehydroxytremetone. The specific toxin causing "milk sickness" has yet to be determined, although tremetone has been shown to be cytotoxic in cell cultures.

Nearly all animals are susceptible to white snakeroot poisoning. Animals must consume approximately $5-10 \%$ of their body weight over a period of a couple of days to weeks in order to show clinical signs of poisoning. Tremetol compounds are excreted in the milk; thus, nursing young are also commonly affected and often show clinical signs before the lactating dam. Although nearly all animals are affected by white snakeroot, most recently reported cases of poisoning have occurred in horses. Most cases of poisoning occur in late summer, fall, or early winter when other, more preferred, forages are depleted. Clinical signs usually take several days to appear and are initially presented as listlessness and reluctance to move. Animals appear to have joint stiffness and will stand in a slightly humped position. They will have an increased and often times irregular heart rate along with an increased and "jerky" respiratory rate. 
Affected animals will also have marked increase in the serum enzymes lactate dehydrogenase and creatine kinase, which are indicators of muscle damage.

Depending upon severity of the disease, some animals will recover following a period of weakness and decreased appetite. Affected animals should be allowed to remain quiet and have access to high-quality feed and water. Once an animal recovers, the long-term affects on cardiac capacity and production are unknown; however, it is likely that they will be permanently impaired.

Pastures containing white snakeroot should not be overgrazed, and animals should be removed by late summer to avoid intoxication. Herbicidal control (see Table 1) or physical removal of white snakeroot is recommended in order to avoid exposure of livestock.

\section{Rayless Goldenrod}

Rayless goldenrod (Isocoma wrightii, Happlopappus heterophyllus, or Isocoma pluriflora) is a toxic range plant found in the southwestern United States commonly growing in soils that are alkaline or contain gypsum, along riparian zones in river valleys, drainage areas, or dry plains. Livestock losses were reported for Colorado, Arizona, New Mexico, and Texas. The disease caused by its consumption was initially referred to as "alkali disease" because it was mistakenly associated with drinking of alkali water. Similar to white snakeroot, the toxin in rayless goldenrod is believed to be tremetol. Chemical analysis of rayless goldenrod shows many of the same tremetone-like compounds as in white snakeroot, albeit in different proportions and concentrations.

Toxicity occurs after consumption of $5-15 \%$ of the animal's body weight during a 1-3-week period. Like white snakeroot, tremetol is excreted in the milk, poisoning the

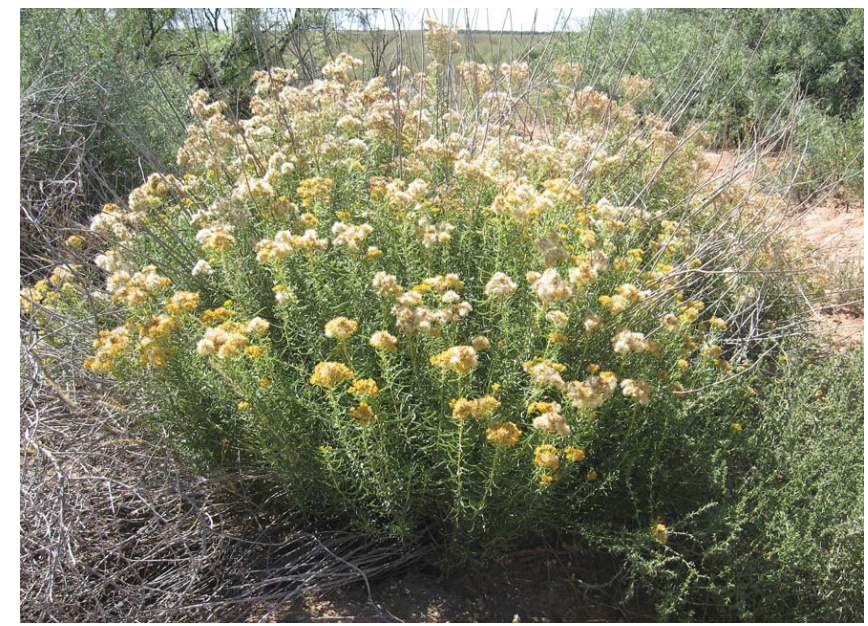

Rayless goldenrod (courtesy of Dr Samantha R. Uhrig, Desert Willow Veterinary Services, LLC, Carlsbad, New Mexico)

nursing young. Initial signs are depression, reluctance to eat, and inactivity followed by fine muscle tremors of the nose and legs, which are especially evident following exercise or activity. Most cases of poisoning are characterized by rapid breathing, increased heart rate, stiff gait, and standing in a "humped up" position.

Most cases of poisoning occur in winter or early spring and are often a result of overgrazing pastures, thus forcing livestock to consume rayless goldenrod because better quality forages are no longer available. Livestock are also commonly poisoned when snowstorms cause other forages to be covered and rayless goldenrod is the predominant forage showing above the snow.

In order to avoid poisoning of livestock, it is important to use good management practices and avoid overgrazing

Table 1. Herbicide control of selected poisonous plants

\begin{tabular}{|c|c|c|c|}
\hline Plant & Herbicide & Rate (Ib/ac or oz/ac) & Comments \\
\hline White snakeroot & Dicamba & $1-4 \mathrm{lb} / \mathrm{ac}$ & \\
\hline \multirow[t]{2}{*}{ Rayless goldenrod } & Picloram & $1-2 \mathrm{lb} / \mathrm{ac}$ & Late summer, early fall \\
\hline & Tebuthiuron pellet ( $20 \%$ ai) & $1.0 \mathrm{lb} / \mathrm{ac}$ & Summer, prior to rain \\
\hline Death camas & 2,4-D & $1.5-3 \mathrm{lb} / \mathrm{ac}$ & Early spring \\
\hline \multirow[t]{4}{*}{ Poison hemlock } & Telar & $1.0 \mathrm{oz} / \mathrm{ac}$ & \multirow{2}{*}{$\begin{array}{l}\text { Before sprouts emerge (may require } \\
\text { repeated applications) }\end{array}$} \\
\hline & Escort & $1.0 \mathrm{oz} / \mathrm{ac}$ & \\
\hline & $2,4-D+$ & $2.5+\mathrm{lb} / \mathrm{ac}$ & $\begin{array}{l}\text { Before bud stage (may require } \\
\text { repeated applications) }\end{array}$ \\
\hline & Dicamba & $1 \mathrm{lb} / \mathrm{ac}$ & Before bud stage \\
\hline Water hemlock & $2,4-\mathrm{D}$ & $2 \mathrm{lb} / \mathrm{ac}$ & Bud to early bloom \\
\hline \multirow[t]{2}{*}{ Broom snakeweed } & Tordon & $0.25-0.5 \mathrm{lb} / \mathrm{ac}$ & Fall following flowering in South \\
\hline & Escort & $0.5 \mathrm{oz} / \mathrm{ac}$ & Spring during active growth in North \\
\hline
\end{tabular}

Abbreviations: lb/ac is pounds per acre; oz/ac, ounces per acre; and ai, active ingredient. 
pastures with rayless goldenrod. Supplementing hay during winter or early spring storms may be necessary to prevent livestock from grazing the plant. Herbicides can be applied during the late summer or early fall to effectively control rayless goldenrod (see Table 1 ).

\section{Death Camas}

There are many species of death camas (Zigadenus spp.) in the western United States and Canada; at least five species are reported to be toxic to livestock, although all death camas species are assumed to be toxic. The habitat of death camas ranges from dry hillsides and plains to moist mountain valleys. Death camas toxicity varies significantly depending upon species and variety, season, climate, soils, and geographic location. The bulbs, leaves, and fruit are all toxic. The leaves contain high concentrations of alkaloids during early stages of growth when the risk of toxicosis is greatest. The three species that present the most serious hazards to livestock, in order of toxicity, are Nuttall's death camas (Zigadenus nuttallii), meadow death camas (Zigadenus venosus), and foothill death camas (Zigadenus paniculatus). The toxins in death camas are steroidal alkaloids.

Poisoning by death camas usually occurs early during the spring when they are prevalent in areas where grasses are dormant or unavailable. Death camas has a very bitter taste and is unpalatable. However, death camas grows quickly

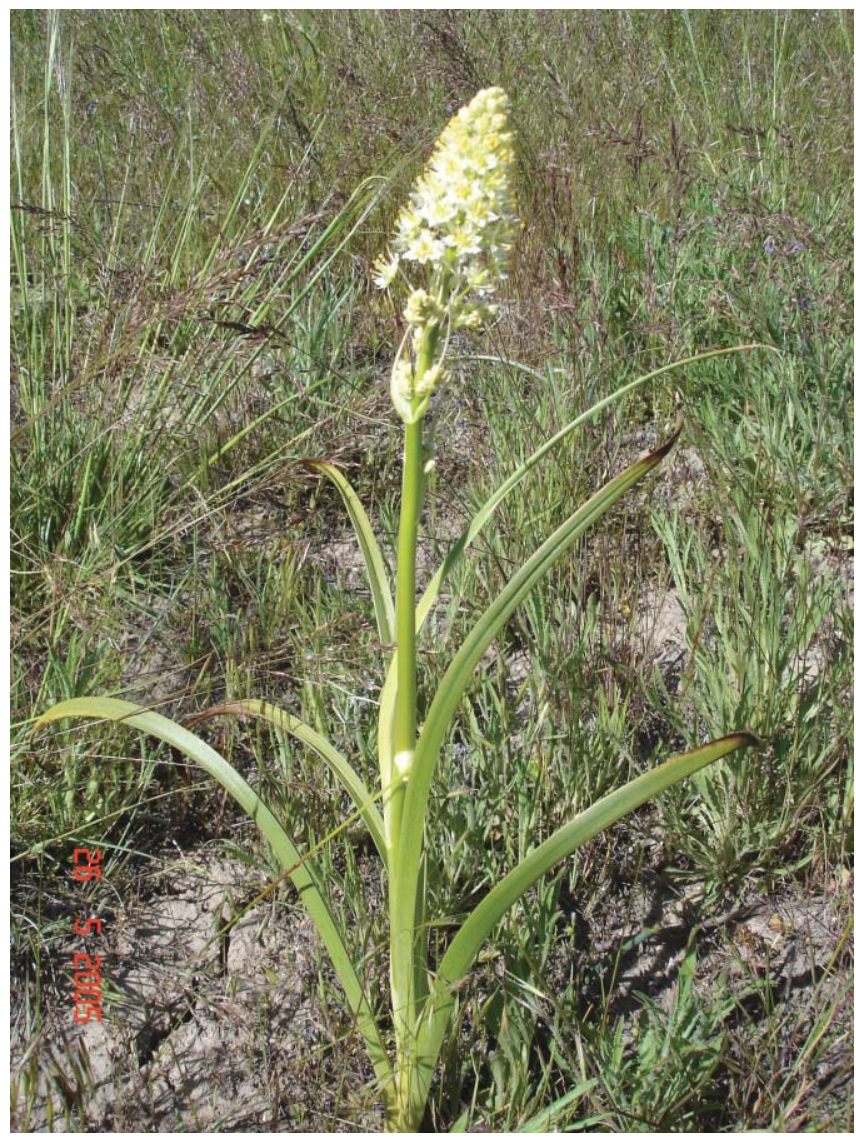

Death camas early in the spring, before other more palatable forbs and grasses appear, and is often consumed because of the lack of other forages. Other cases of poisoning occur when pastures or ranges are overgrazed and more palatable feeds are no longer available. In some of the more toxic species, doses of $0.2-0.5 \%$ of body weight will cause serious illness or death. In lambs, $0.22-0.88$ pounds $(0.1-0.4 \mathrm{~kg})$ of plant material, or 30-100 plants, may be toxic. Sheep are most commonly poisoned by death camas because of their smaller size and grazing habits. However, cattle, horses, fowl, swine, and humans have died by consuming death camas. Generally cattle deaths are uncommon because of their larger size and the fact that they usually eat small amounts of the toxic plant. Typically horses are affected by death camas only when it is fed in contaminated hay.

Clinical signs are similar in all animal species; however, variation among species does occur in the duration and severity of the symptoms. Initial poisoning symptoms include profuse, frothy salivation accompanied by depression, nausea, teeth grinding, and vomiting. As poisoning progresses, the animal will quit eating, begin trembling, then lose muscular coordination and appear weak. If sufficient toxins are ingested the animal becomes comatose, breathing is labored, and death occurs from respiratory failure.

Because death camas is most toxic in the spring, caution should be taken to not graze livestock in areas where death camas is growing if other forages are lacking. Sheep should also be bedded in areas away from death camas so it is not the first forage available as they begin grazing in the morning when they are the hungriest and are less selective among plants to include in their diet. If animals are poisoned, they should be moved out of the area slowly and quietly to prevent exacerbation of the clinical signs and increased losses that can occur with stress. Death camas can be controlled in heavily infested areas with herbicides such as 2,4-D (see Table 1).

\section{Halogeton}

Halogeton (Halogeton glomeratus) is a noxious and poisonous plant introduced into the United States from Asia during the early 1900s. It was first collected in 1934 along

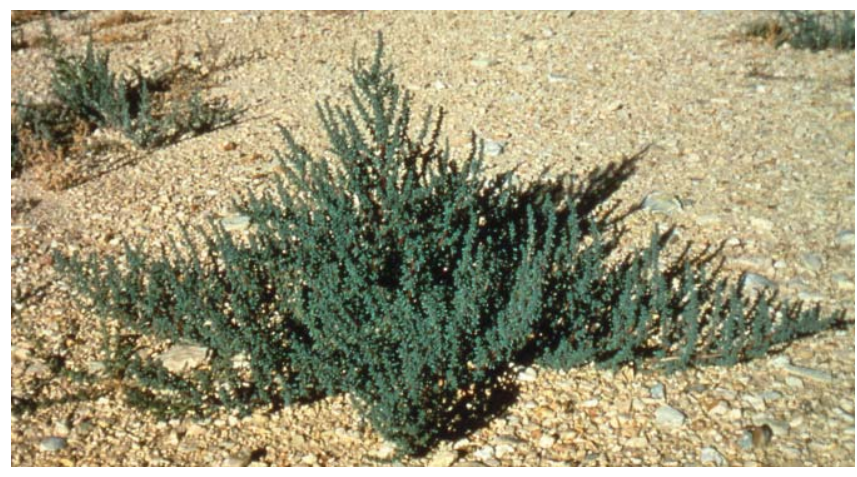

Halogeten 
the railroad tracks near Wells, Nevada. It spread quickly across 11.2 million acres (4.5 million ha) of the western desert regions, which provided ideal conditions for its growth and unabated expansion. Catastrophic livestock losses occurred during the mid-1900s when entire bands of sheep were poisoned. In these instances sheep were often trailed, or transported long distances. Upon arrival, hungry and thirsty sheep were usually released at commonly used trail heads or water holes that had been denuded of native vegetation and subsequently invaded by pure stands of halogeton. Hungry sheep consumed large amounts of halogeton and were rapidly poisoned. The result was the death of large bands of sheep.

Halogeton has a specific ecological niche in which it grows. It is commonly found in the Great Basin, the Red Desert of Wyoming, and the Colorado Plateau in salt-desert shrub and sagebrush plant communities that receive little precipitation. Halogeton usually invades previously disturbed areas where there are no competing perennial shrubs or grasses. Conversely the establishment of halogeton can be prevented by maintaining healthy stands of native or other desired plant communities. Halogeton growth usually occurs during midsummer when cheatgrass and native perennials are mature, dormant, or dead. With few competitors, halogeton is able to rapidly use summer rainfall for growth and seed production and ultimately dominate large areas.

Halogeton is a prolific seed producer, which enables its rapid spread across intermountain rangelands. A single halogeton plant can produce over 100,000 seeds, which are either black or brown. Black seeds are capable of germinating anytime that the temperature and moisture content of the soil is favorable for germination; thus, halogeton can exploit the desert's erratic weather patterns. The brown seeds are capable of surviving for long periods of time in the harsh extremes of the desert soil and germinating in the more distant future when reoccurring conditions are favorable. Such a seemingly clever scheme ensures halogeton's long-term persistence in the plant community.

Halogeton's toxins are potassium and sodium oxalate, which are also sometimes referred to as soluble oxalates. Poisoning usually occurs during the fall and early winter when oxalate concentrations reach $20-30 \%$ of the plant's dry matter weight and other forages are scarce. By early spring soluble oxalate concentrations have decreased to approximately $5 \%$ of the plant, and there is very little risk of poisoning.

Rumen microflora in sheep and cattle can be preconditioned to detoxify oxalates by feeding low levels of oxalates. Oxalates may also bind to calcium in the gastrointestinal tract, forming insoluble calcium oxalate, which is excreted in the feces. Poisoning occurs when the oxalate concentrations exceed the capacity of ruminal microorganisms to detoxify them. This results in oxalate being absorbed into the bloodstream, forming calcium oxalate crystals that cause hypocalcemia, impeded energy metabolism, shock, and death. These calcium oxalate crystals may be deposited in the walls of ruminal arterioles, causing ruminal hemorrhages, and/or they can precipitate out in the renal tubules, resulting in kidney damage and eventual death. The signs shown by animals poisoned by halogeton include anorexia, depression, weakness, and incoordination followed by recumbency, nasal discharge, and eventually coma and death. A lethal dose of halogeton in sheep can be as little as 12 ounces $(340 \mathrm{~g})$, and death associated with hypocalcemia and impaired energy metabolism usually occurs within 9-11 hours.

Herbicidal control of halogeton is impractical, because herbicides also kill native shrubs and thereby decrease effective competitors of halogeton and subsequently promote the spread of halogeton over larger areas. However, recommendations are available to avoid halogeton poisoning in sheep that include, but are not limited to, the following: 1) avoid overgrazing the range, 2) develop a grazing program, improving range quality, 3) reduce grazing pressures during drought, 4) avoid grazing, or lightly graze, perennial vegetation during the growing season, 5) provide adequate water, 6) watch your livestock, 7) precondition sheep by short-term intermittent exposure to oxalate-containing forage, 8) gradually introduce animals to halogeton-dominated areas, 9) do not allow hungry animals to graze in large, dense areas of halogeton without first being fed and watered, and 10) do not trail thirsty sheep into watering places surrounded by halogeton.

\section{Poison Hemlock}

Historically poison hemlock (Conium maculatum) is reported to have been used to make a "tea" used to execute criminals in ancient Greece. The "Hemlock tea" was used to execute Socrates, the Greek philosopher, for promoting ideas contrary to the political and religious views of that era. Poison hemlock is still listed in European pharmacopea. Poison hemlock is found throughout North America and

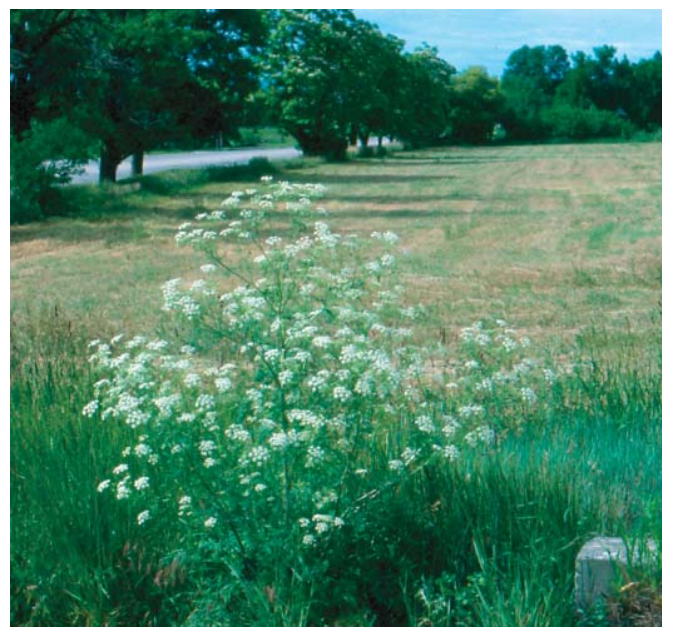

Poison hemlock 
grows in dense stands along ditch banks, fence rows, and roadsides, in moist undisturbed areas. The leaves resemble carrot tops, and stems have purple spots, a distinguishing feature.

Poison hemlock contains several volatile piperidine alkaloids, with the most abundant being $\gamma$-coniceine, coniine, and $N$-methylconiine. The concentrations and relative proportions of the toxins change in the plant from day to day and even diurnally as the plant grows and matures. Alkaloids are synthesized in the vegetative portions of the plant and are translocated to the seeds and flower portions. In general, the toxins accumulate to attain their greatest concentrations in the seeds and flowers. When estimating the relative toxicity of poison hemlock, one must consider total alkaloid content and the relative amount of the individual alkaloids. The toxicity of the various alkaloids varies greatly, with $\gamma$-coniceine being the most toxic, followed by coniine and $N$-methylconiine.

At relatively larger doses poison hemlock is acutely toxic, causing death. When ingested repeatedly at smaller doses it can cause birth defects. In acute intoxications the alkaloids cause a neuromuscular blockade, muscular weakness, and death due to respiratory failure. Teratogenic consequences, or birth defects, resulting from ingestion of poison hemlock are reported in pigs and cattle. The susceptible stages of pregnancy occur during the first 30-60 days of gestation in pigs and 40-70 days in cattle. The mechanism of the birth defects is inhibited fetal movement, resulting in skeletal abnormalities and cleft palate.

Signs of poisoning can manifest themselves within 15 minutes after consuming poison hemlock. Early signs are tremors, nervousness, excess salivation, increased frequency of urination and defecation, and muscular weakness, which progresses to collapse and death if doses are high enough. If death does not occur, then recovery is usually complete within 24 hours with little evidence of intoxication.

Caution should be taken to avoid putting hungry livestock in areas infested with poison hemlock. If an animal becomes poisoned, avoid stressing the animal and allow it to quietly recover. Poison hemlock can be controlled using broad-leaf herbicides (see Table 1); however, repeated herbicide applications might be required until seeds residing in the soil are depleted.

\section{Water Hemlock}

Water hemlock (Cicuta spp.) is among the most toxic plants known. Ingestion of very small amounts can lead to violent seizures and death. Water hemlock is widely distributed in North America. Unlike poison hemlock it seldom grows in dense stands but grows along active streams and waterways.

Water hemlock is usually considered a perennial herb; however, it is more correctly classified as a biennial because it does not produce seeds until the second year. Water hemlock is distinguished from poison hemlock by its serrated

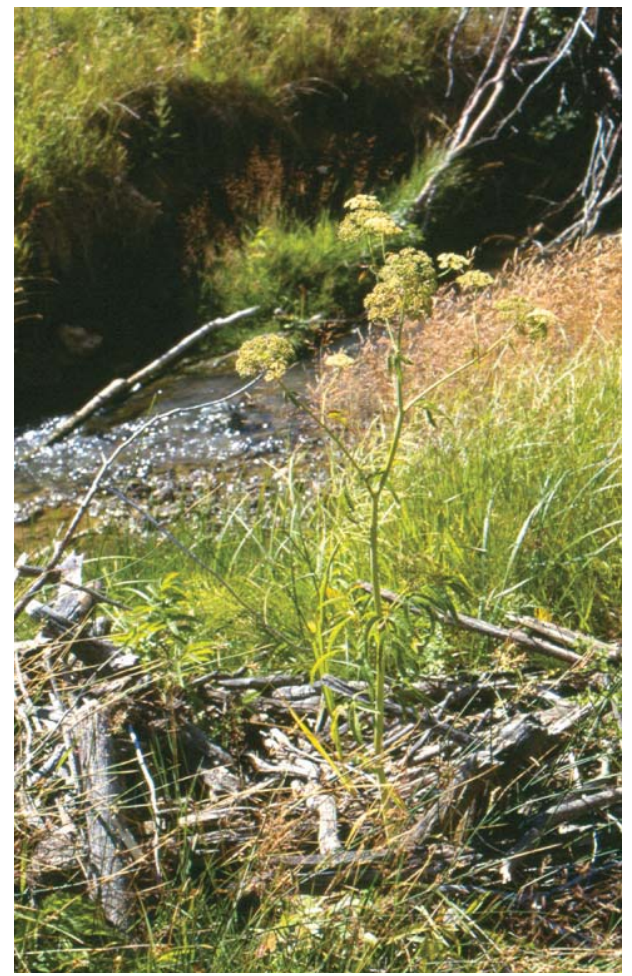

Water hemlock

leaves and tuberous root system. Parsnip-like roots radiate out from the central tuber and are especially distinct in early spring. The tuber is the most poisonous part of the plant.

The toxins in water hemlock are long chain alcohols, concentrated in the oily, yellowish liquid that oozes from the lower stem or tuber when cut. Cicutoxin and cicutol are the main toxins that concentrate in the tubers. Early spring is usually the time when ingestion is most likely to occur. As the plant grows, the toxins decrease per unit of volume; thus more plant must be ingested for poisoning to occur.

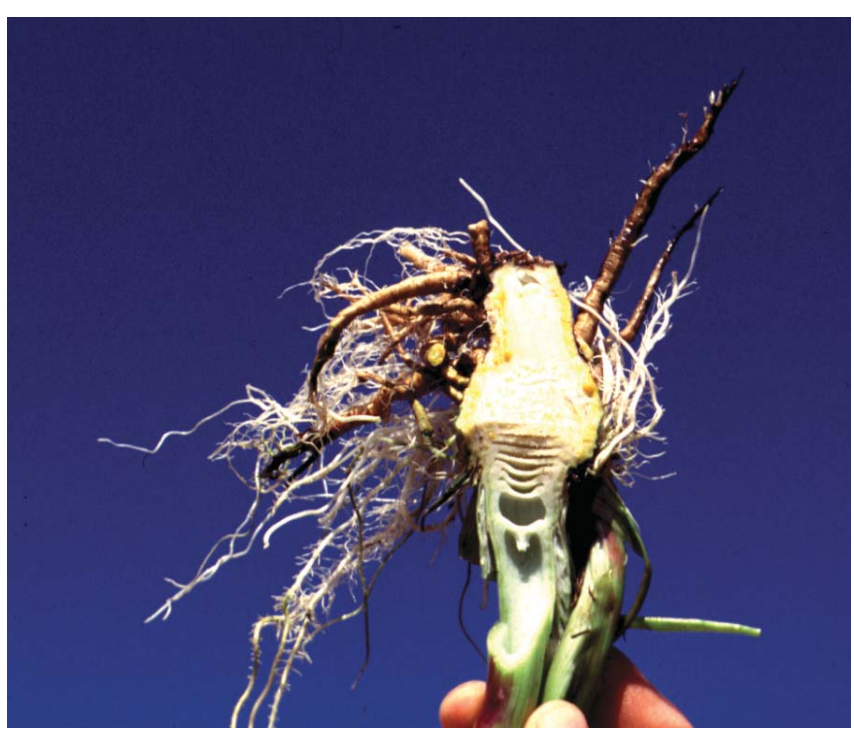

Water hemlock root 
If tubers are consumed, as little as $0.5 \%$ of body weight or a portion of a single tuber may be lethal. The toxic effects of water hemlock are rapid and severe following ingestion. Within 15-30 minutes after ingesting water hemlock, clinical signs such as twitching of the lips, nose, ears, and face muscles are visible. Soon thereafter, convulsions and grand mal seizures begin. The seizures become prolonged and more violent with time ending in death within 4-12 hours depending on the amount ingested. Death can be prevented by controlling seizures using barbiturates; however, intervention must be soon after signs of poisoning become visible in order to be successful.

Plants are easily identified when mature and can be controlled with herbicides (see Table 1) or physical removal. If plants are physically removed, then care is required to prevent tubers from being eaten by animals because the tubers are quite palatable.

\section{Broom Snakeweed}

Broom snakeweed (Guterrezia sarothrae) is widely distributed in western North America, ranging south from Canada, throughout the Great Plains to West Texas and northern Mexico, and distributed west through the Intermountain region and into California. Broom snakeweed grows at elevations from 4,000 feet and 8,000 feet and commonly inhabits dry, well-drained, sandy, gravely, or clayey loam soils.

Broom snakeweed is a native subshrub that increases with disturbances such as overgrazing, fire, and drought, to the point that it can dominate plant communities. Snakeweed typically establishes during wet years following drought, wildfire, or intensive grazing. This type of pulse establishment produces massive even-aged stands that subsequently become susceptible to die-off from insect damage and drought. These factors drive snakeweed population cycles that have been reported on blue grama grasslands in New

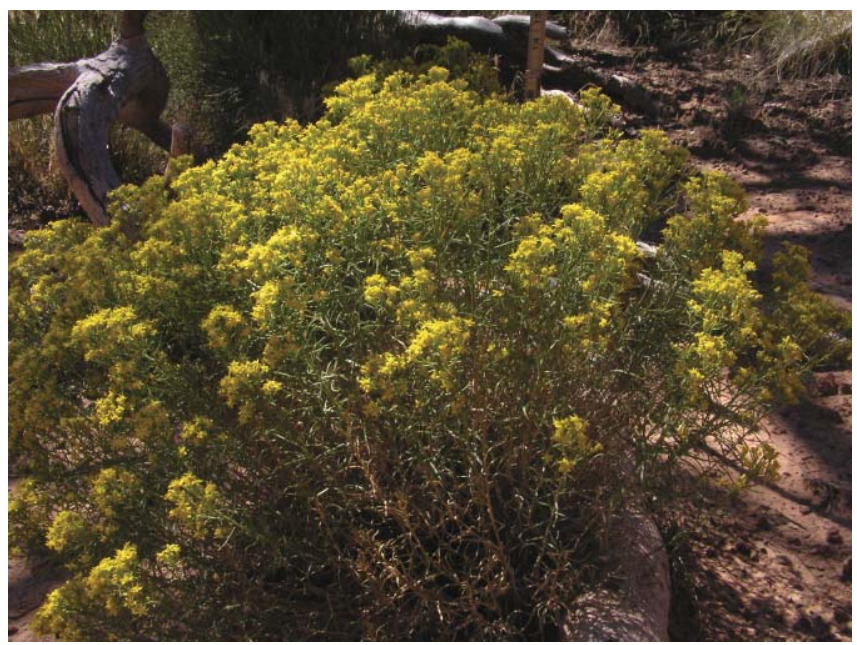

Broom snakeweed (photo courtesy and copyright Al Schneider, http:// www.swcoloradowildflowers.com)
Mexico, in salt desert shrub communities on the Colorado Plateau, and in crested wheatgrass seedings on the Snake River plain.

Once established, broom snakeweed is very competitive. Snakeweed's root structure and rooting depth provide a competitive advantage over most associated grass species. Furthermore, stomates on snakeweed leaves do not close completely, resulting in heavy water consumption by stands of broom snakeweed that hastens depletion of soil water needed by associated grasses.

Although broom snakeweed is not palatable, it can be toxic and possibly cause abortions if consumed by livestock. The toxic and potentially abortifacient compounds from snakeweeds have not been fully identified. Saponins have been suggested as the toxic constituents and furanoditerpene acids that are structurally similar to isocupressic acid, the abortifacient compound in ponderosa pine needles, have been reported. Snakeweed is toxic, and clinical signs of intoxication include anorexia, mucous-like nasal discharge, listlessness, and diarrhea followed by constipation and rumen stasis, which can eventually lead to death.

Broom snakeweed can be controlled by prescribed burning and herbicides. Prescribed burning is recommended during the early stages of snakeweed infestations, when there is sufficient grass to carry a fire. However, once snakeweed dominates a site, herbicides are recommended for control (see Table 1). Effective snakeweed control requires that the resulting plant community sufficiently occupy plant resources in order to prevent snakeweed reestablishment. Seeding native and introduced cool-season grasses can prevent reestablishment of snakeweed and prevent the growth of cheatgrass. Maintaining optimal grass cover in the plant community can prevent snakeweed dominance while providing forage that will avert livestock from eating snakeweed and prevent subsequent poisoning.

\section{Summary}

Poisonous plants growing on US rangelands cause significant economic losses to livestock producers. It is important that livestock owners and producers are familiar with potentially toxic plants growing in their area and use available knowledge about the ecology and physiology of these plants to avoid livestock losses. Few treatments are available for livestock poisoned by toxic plants. Therefore preventing livestock access to toxic plants during conditions when poisoning may occur is critical. For example, many poisonous plants are palatable, or their toxin concentrations are high enough to poison livestock, only during specific time periods. Similarly, livestock may be susceptible to the toxins in poisonous plants only during specific times, such as critical periods of pregnancy; otherwise, these plants can be safely consumed. Additionally, many poisonous plants are grazed only when more preferred forages are depleted, emphasizing the need for land owners and managers to responsibly manage their ranges and pastures. In conclusion, 
if producers are well acquainted with the ecology and physiology of the plants growing on their ranges, management strategies can be developed to reduce livestock exposure and avoid poisoning.

\section{Additional Reading}

Burrows, G. E., And R. J. Tyrl. 2001. Toxic plants of North America. Ames, IA, USA: Iowa State University Press. 1,342 p.

Cook, C. W., And L. A. Stoddart. 1953. The halogeton problem in Utah. Logan, UT, USA: Utah Agricultural Experiment Station Bulletin 364. 44 p.

Kingsbury, J. M. 1964. Poisonous plants of the United States and Canada. Englewood Cliffs, NJ, USA: Prentice-Hall. 626 p.

Knight, A. P., and R. G. Walter. 2001. A guide to plant poisoning of animals in North America. Jackson, WY, USA: Teton New Media. 367 p.

Roitman, H. N., L. F. James, and K. E. Panter. 1994. Constituents of broom snakeweed (Gutierrezia sarothrae), an abortifacient rangeland plant. In: S. M. Colgate and P. R. Dorling [EDs.].
Plant-associated toxins: agricultural, phytochemical and ecological aspects. Wallingford, United Kingdom: CAB International. p. 345-350.

Young, J. A., P. C. Martinelli, E. E. Richard, and A. E. RAYMOND. 1999. Halogeton: a history of mid-20th century range conservation in the intermountain area. Washington, DC, USA: US Government Printing Office, USDA-ARS Miscellaneous Publication No. 1553. 60 p.

Authors are Research Biochemist, zane.davis@ars.usda.gov (Davis), Research Chemist (Lee), Rangeland Scientist (Ralphs), and Reproductive Toxicologist and Research Leader (Panter), Poisonous Plant Research Laboratory, Agricultural Research Service, United States Dept of Agriculture, $1150 \mathrm{E} 1400 \mathrm{~N}$, Logan, UT 84341, USA. Published with the approval of the Director as Journal Paper No. 8042 of the Utah Agricultural Experiment Station. A full citation section can be found at http://www.srmjournals.org. 